\title{
CFO characteristics and opportunistic accounting choice in public sector organizations
}

\author{
Pierre Donatella ${ }^{1} \cdot$ Torbjörn Tagesson $^{2}$ (1)
}

Published online: 31 July 2020

(c) The Author(s) 2020

\begin{abstract}
Two different theoretical foundations in the literature relate to the quality of financial reporting in public sector organizations: one theoretical foundation is based on economic theory, and the other is based on institutional theory. In addition to examining the traditional factors derived from these theories, this paper focuses on the role of the chief financial officer (CFO), in order to broaden the theoretical perspective and add explanatory power with regards to the empirical testing of opportunistic accounting choice in public sector organizations. Similar to AnessiPessina and Sicilia (J Public Adm Res Theory, 30:465-484, 2019), this paper uses upper echelons theory (Hambrick and Mason in Acad Manage Rev, 9(2):193-206, 1984; Hambrick in Acad Manage Rev, 32(2):334-343, 2007) to conceptually link CFO characteristics with opportunistic accounting choice. The accounting issue addressed herein is related to a statement issued by the standard-setting body within the Swedish municipal sector. Our results suggest that opportunistic accounting choice decreases with $\mathrm{CFO}$ tenure and prior $\mathrm{CFO}$ experience in municipalities.
\end{abstract}

Keywords CFO, compliance $\cdot$ Earnings management $\cdot$ Accounting choice $\cdot$ Public sector $\cdot$ Upper echelons theory

\section{Introduction}

At present, there are two major streams of literature relating to financial reporting quality in public sector organizations. One stream focuses on analysing compliance issues (e.g. Jones and Pendlebury 1982, 1991, 2004; Ingram 1984; Lin et al. 1993; Giroux and Deis 1993; Christiaens 1999; Carvalho et al. 2007; Christiaens and Van Peteghem 2007; Haraldsson and Tagesson 2014; Ada and Christiaens 2017;

Torbjörn Tagesson

torbjorn.tagesson@liu.se

1 School of Public Administration, University of Gothenburg, Gothenburg, Sweden

2 Department of Management and Engineering, Linköping University, Campus Valla,

Linköping 581 83, Sweden 
Donatella 2020a), whereas the other stream is centred on analysing abnormal accruals (e.g. Ballantine et al. 2007; Stalebrink 2007; Pilcher and Van der Zhan 2010; Pina et al. 2012; Ferreira et al. 2013; Arcas and Martí 2016; Greenwood et al. 2017; Beck 2018; Drew 2018; Cohen et al. 2019; Donatella et al. 2019; Ibrahim et al. 2019; Donatella 2020b). More specifically, the latter relates to discretion in financial reporting, and whether this room for manoeuvring is being used opportunistically in order to adjust the reported financial performance (i.e. earnings management in public sector organizations). Considering that non-compliance with regulation is likely to have an impact on reported financial performance, we argue that both these streams of literature relate to opportunistic accounting choice in public sector organizations.

As the early literature on compliance in public sector organizations dates back to the late 1970s, this issue has been an intriguing area of empirical interest for more than 40 years (Christiaens 1999; Rodríguez et al. 2013). During these decades of research, the theoretical approach used to explain variations in levels of compliance between different public sector organizations has evolved, from early research that typically relied on economic theories alone, to more recent literature that has begun to generate explanatory factors from institutional theory as well (Carpenter and Feroz 2001; Collin et al. 2009; Rodríguez et al. 2013). Common factors used to explain compliance include, but are not limited to, political competition, financial conditions, inter-governmental subsidies received, organizational size and wealth of citizens (Rodríguez et al. 2013).

In comparison, the more recently emerging literature on abnormal accruals in public sector organizations are rather limited in theoretical scope. Within this stream of literature, economic theories—such as rational choice or agency theory-are typically used to model adjustments of reported financial performance. Most studies are centred on signalling and regulatory incentives (e.g. Ballantine et al. 2007; Stalebrink 2007; Pina et al. 2012; Arcas and Martí 2016; Greenwood et al. 2017; Beck 2018; Drew 2018), but there are also a few studies that model incentives based on political competition and other political factors (Ferreira et al. 2013; Cohen et al. 2019; Donatella 2020b). Evidence from this stream of literature suggests that public sector organizations are striving to report small surpluses, and adjust the reported financial performance accordingly.

Thus, two different theoretical foundations have emerged in the literature relating to financial reporting quality in public sector organizations: one based on economic theory and one based on institutional theory. Obviously, there are some fundamental differences between these two theoretical perspectives. Economic theories are based on the assumption of utility maximization, and assume that individuals in an organization are homogenous or perfect substitutes (e.g. Downs 1957; Zimmerman 1977; Watts and Zimmerman 1986). In other words, when faced with the same incentives, different individuals are expected to respond in the same rational way, and this is expected to be reflected in accounting choice as well (Ge et al. 2011). In contrast, the basic premises of institutional theory, as originally proposed by scholars such as Meyer and Rowan (1977) and DiMaggio and Powell (1983), is that, in response to pressure stemming from their environment, organizations will adapt formal structures such as financial reporting in order to gain legitimacy. Thus, when using this 
theoretical framework, it is the organizational environment that is in focus when explaining accounting choice (Carpenter and Feroz 2001; Collin et al. 2009).

In addition to the traditional factors derived from economic and institutional theories, we focus on the role of the chief financial officer (CFO) in this paper, in order to broaden the theoretical perspective and add explanatory power with regards to the empirical testing of opportunistic accounting choice in public sector organizations. Similar to Anessi-Pessina and Sicilia (2019), we use upper echelons theory (Hambrick and Mason 1984; Hambrick 2007) to conceptually link CFO characteristics with opportunistic accounting choice in public sector organizations. Unlike economic and institutional theories, upper echelons theory suggests that individuals do matter, and will react in different ways due to individual idiosyncrasies (Hambrick and Mason 1984; Hambrick 2007). Based on this premise, we generate hypotheses on the relationship between CFO characteristics and opportunistic accounting choice. By doing so, we contribute to a limited literature that relates financial reporting issues in public sector organizations to the accounting staff (Anessi-Pessina and Sicilia 2019).

The aim of this paper is to test the relationship between CFO characteristics and opportunistic accounting choice in public sector organizations. The accounting choice at hand is related to a statement issued by the standard-setting body within the Swedish municipal sector.

The remainder of the paper is structured as follows: Sect. 2 briefly describes the context and institutional setting, while Sect. 3 provides the theory from which the hypotheses are derived. In Sect. 4, our sample, data and operationalization of variables are presented and discussed. Section 5 presents the analysis and empirical results, and Sect. 6 provides our conclusions.

\section{Legal and institutional context}

There are a total of 290 municipalities in Sweden. The average number of inhabitants per municipality at the end of 2019 was 35,612. However, the number of inhabitants in a municipality varies considerably, from Stockholm, which is the largest municipality at 974,073, to the smallest municipality of Bjurholm, with 2408 inhabitants (data source: Statistics Sweden).

Swedish municipalities are responsible for a wide range of activities, including preschool, primary and secondary schools, elderly care, social welfare, urban planning, roads, water and sewerage, and waste collection. According to Tagesson and Grossi (2015), the municipalities consume approximately $13 \%$ of the gross national product. Although these obligations are regulated by law, the municipalities are relatively autonomous from the central government in terms of how their duties and activities should be financed, organized and executed (Montin 2015; Tagesson and Grossi 2015). For example, Swedish municipalities have the right to levy their own taxes. Approximately $80 \%$ of a municipality's operations is financed by tax revenues and fees. The remaining $20 \%$ is financed by governmental grants, which are categorized into two main types: (1) general grants with no restrictions (i.e. non-exchange transactions); and (2) targeted grants that carry obligations for the municipalities 
receiving the grant. There is a restriction on municipalities, however: they are generally not allowed to budget and report deficits. There is a legal requirement stating that revenues should cover the expenses for municipal activities every year, and that deficits, if occurring, should be restored by equivalent surpluses over the next 3-year period, unless there are special reasons not to adjust the deficit in such a short period of time or if the municipality can demonstrate a strong financial position (Donatella 2020b). Consequently, surpluses are not accumulated over time, whereas deficits are accumulated and are required to be restored. This situation results in a requirement that is asymmetric in nature, which - as we will discuss later-may incentivize municipalities to adjust their reported financial performance. In addition, just as in other country settings with similar prerequisites, political signalling incentives are likely to exist. On the one hand, if deficits are reported, governing parties risk facing negative attention and criticism over reckless policies (Pilcher and Van der Zhan 2010; Arcas and Martí 2016); on the other hand, if large surpluses are reported, they risk facing criticism over excessive taxation (Stalebrink 2007; Ferreira et al. 2013) or failure to increase the quality of the activities provided for voters and other potential stakeholders (Pilcher and Van der Zhan 2010).

Sweden was one of the early adopters of accrual accounting in municipalities (Tagesson and Grossi 2015), and a set of local generally accepted accounting principles (GAAP) has been in use since 1986 (Brorström 1997). Since 1998, the financial reporting in municipalities has been regulated by a framework legalization, which explicitly refers to the GAAP expressed in the standards and statements issued by the Swedish Council for Municipal Accounting (SCMA). In addition to the 18 accounting standards published by the SCMA at the time of this study, the standard setter had proposed statements on specific accounting issues. The regulation in use essentially corresponds to the standards issued by the International Public Sector Accounting Standards Board (PwC 2014).

Although decisions related to financial reporting can be appealed in administrative courts, there is no link between municipal accounting legalization and the penal code (Falkman and Tagesson 2008). As there is no oversight body or other government control of financial reporting, the control of compliance with GAAP and legalization lies with the municipal residents and elected political auditors. Political auditors should scrutinize financial reporting and provide a statement of whether the reporting gives a true and fair view. In this inspection, they are assisted by experts, who are normally a service procured from one of the "Big Four" audit firms (Tagesson et al. 2015). Only a few municipalities have their own audit office with such competency (Collin et al. 2017).

Considering the absence of a link between regulation and the penal code, the risk associated with deviating from GAAP and legalization is not related to legal sanctions. Rather, in the setting of Swedish municipalities, the risk associated with noncompliance is essentially political in nature (Donatella 2020b); for example, a questionable accounting practice can result in negative attention in the mass media and elsewhere, which may decrease the chances of re-election for governing parties (e.g. Zimmerman 1977).

Elections, in which municipal residents have the right to vote, occur every 4th year. Based on the voting outcome, the seats in the municipal council are distributed 
between the representatives of political parties. The municipal council subsequently selects the municipal executive board, which is then constitutionally responsible to the council. Historically, a coalition of either right-wing or left-wing parties has typically held the majority of seats in the municipal council and the municipal executive board (Montin 2015).

\section{Theoretical framework}

\subsection{Upper echelons theory}

Unlike economic and institutional theories, upper echelons theory (Hambrick and Mason 1984; Hambrick 2007) postulates that top executives will affect organizational outcomes in different ways. According to the theory, this is because when bounded rational individuals (Cyert and March 1963) are faced with situations requiring strategic choices, such as financial reporting decisions, they are unable to fully comprehend and thoroughly process these complex tasks (Plöckinger et al. 2016). In decision-making situations, individuals will instead simplify and reduce the richness of detail being taken into account. As these processes of simplification are constructed by an individual's cognitive base and values, upper echelons theory suggests that the decisions and outcomes will reflect individuals' experiences, personality and other idiosyncrasies (Hambrick and Mason 1984; Hambrick 2007). However, the latitude of discretion — that is, the '(...) absence of constraints from environmental, organizational, or personal conditions and, at the same time, the presence of multiple plausible decision alternatives' (Plöckinger et al. 2016, p. 57) - is predicted to moderate the relationship between top executives' individual characteristics and the decisions and outputs. More precisely, it is suggested that top executives' individual characteristics are reflected more in decisions and outputs made under high discretion than in those made under low discretion (e.g. Hambrick and Finkelstein 1987; Hambrick 2007).

Since the original theory paper was published by Hambrick and Mason (1984), upper echelons theory has generated a considerable amount of empirical research analysing the relationship between strategic choice and top executives' characteristics in a number of different settings (for a literature review, see Nielsen 2010; Hiebl 2014; Yamak et al. 2014; Plöckinger et al. 2016). In general, the basic proposition in upper echelons theory-that is, that top executives' individual idiosyncrasies affect organizational outcomes - has been supported by empirical findings (Nielsen 2010; Hiebl 2014; Yamak et al. 2014). Upper echelons theory is also supported in financial reporting, as empirical findings have shown that the CEO's and CFO's characteristics are reflected in the financial reporting information that listed companies (Plöckinger et al. 2016) and public sector organizations (Anessi-Pessina and Sicilia 2019) provide to external stakeholders. However, the literature typically emphasizes that financial reporting issues are somewhat different than many other decision-making situations due to regulations, external audits and other institutional constraints that limit top executives' discretion (e.g. Ge et al. 2011). 
When relating upper echelons theory to municipalities, it should be considered that the reporting environment is typically characterized by a rather weak audit function and by a lack of an oversight body or other type of government-imposed control of financial reporting (e.g. Carvalho et al. 2007; Christiaens and Van Peteghem 2007). Such criticism applies to Swedish municipalities (e.g. Haraldsson and Tagesson 2014). Thus, although external constraints are placed upon the reporting entity, there will generally still be room for non-compliance, and therefore multiple alternatives for accounting choice. We acknowledge other potential constraints on CFOs, but nonetheless argue that $\mathrm{CFO}$ characteristics are likely to add explanatory power when used to complement economic and institutional theories in explaining opportunistic accounting choice in public sector organizations with the abovementioned legal and institutional features.

\subsection{Hypotheses}

\subsubsection{CFO tenure}

Outright deviation from the GAAP and legislation, as well as other types of questionable financial reporting practices, always carries a political risk (Donatella 2020b). Considering that a CFO runs the risk of becoming the scapegoat if such irregularities are publicly exposed (Leone and Liu 2010; Hazarika et al. 2012), it is logical to relate opportunistic accounting choice to the risk propensity of CFOs (Anessi-Pessina and Sicilia 2019). At the same time, internal pressure on accounting staff typically arises in financial reporting (Falkman and Tagesson 2008; Anderson et al. 2019) and, for a CFO, there will also be a risk associated with not complying with the will and interest of the governing political parties. Therefore, whether or not CFOs engage in an opportunistic accounting choice may be contingent on the extent to which they have influence over the political process.

Depending on prior work experiences, differences in human capital are likely to arise between CFOs. Of the three types of human capital discussed by Castanias and Helfat (1991, 2001), a long-term employee is likely to have acquired more organization-specific than sector-specific and occupational human capital (Finkelstein and Hambrick 1990). Considering this, long-tenured CFOs should have greater internal credibility than short-tenured CFOs, and should thus be better equipped to withstand political pressure to engage in an opportunistic accounting choice. Furthermore, a CFO's knowledge and understanding of how the internal political process functions in a specific municipality is also likely to increase with tenure. This suggests that long-tenured CFOs are more likely to be able to intervene in the political process than short-tenured CFOs. In other words, a CFO's latitude of discretion in relationship to governing parties should increase with tenure, and should thus result in greater room for manoeuvring and decision-making based on professional norms.

There are also arguments that support differences in risk tolerance between younger and less experienced CFOs, and older and more experienced ones (e.g. Esteve et al. 2013). These arguments suggest that the experience that comes with tenure should make CFOs more reluctant to engage in an opportunistic accounting 
choice. As the human capital tied to the CFO's current position (i.e. the organization-specific human capital) increases over time, it can be expected that long-tenured CFOs, in the absence of strong political pressure, will have more to lose than to gain by engaging in an opportunistic accounting choice, since making such a choice could ultimately cause them to lose their job and thereby lose much of the human capital acquired during their career as well. Finally, there is empirical evidence from private sector research that gives credibility to the outlined arguments of a negative relationship between tenure and opportunistic accounting choice (e.g. Aier et al. 2005; Feng et al. 2011; Hazarika et al. 2012; Schrand and Zechman 2012; Ali and Zhang 2015). We therefore hypothesize that:

H1 The probability of an opportunistic accounting choice decreases with CFO tenure.

\subsubsection{Prior CFO experience}

Although there are a few exceptions (e.g. Aier et al. 2005), the literature devoted to explaining financial reporting quality does not usually link the CFO's prior work experience to the financial reporting outcome. However, prior work experience within an occupation is recognized as an additional source of human capital (Castanias and Helfat 1991, 2001), and such experiences from various organizations and sectors shape the lens through which managers view different problems and opportunities (Hambrick and Mason 1984). Thus, similar to the argument outlined above in support of a negative association between tenure and opportunistic accounting choice, it could be argued that CFOs with more experience and occupational human capital will have greater ability to withstand political pressure to engage in an opportunistic accounting choice than CFOs with less experience and occupational human capital. This leads us to the hypothesis that:

H2a The probability of an opportunistic accounting choice decreases with prior working experience as a CFO, regardless of sector.

On the other hand, some arguments suggest that the sector-specific human capital acquired from prior CFO experience in municipalities will be of greater importance than more general occupational human capital acquired from a CFO's experiences in other sectors. More specifically, municipalities are different from private sector and other public sector settings in Sweden. Unlike private corporations, public sector organizations are not subject to taxation; and, unlike other organizations, whether public or private, a municipal board consists of representatives of both the governing parties and the opposition (Montin 2015). Consequently, goal congruence cannot be expected in a municipal board. In municipal organizations, the CFO works with politicians and is expected to serve representatives from both the governing parties and the parties forming the opposition. As these experiences shape the lens through which managers view different problems and opportunities (Hambrick and Mason 1984), CFOs relying on more general occupational human capital may sometimes 
have difficulty understanding and reconciling these differences in internal political processes. The CFO's ability to withstand political pressure to engage in an opportunistic accounting choice can thus be expected to be contingent on the human capital that is sector-specific, rather than on the human capital that is occupational. This suggests a negative association between prior CFO experience in municipalities and opportunistic accounting choice. Furthermore, similar to the assumption that CFO tenure decreases the CFO's risk propensity, it could be expected that CFOs who have acquired more human capital specific to the municipal sector than human capital related to the occupation of CFO in general will be more risk averse. If accounting irregularities are publicly exposed and the CFO becomes the scapegoat (Leone and Liu 2010; Hazarika et al. 2012), there is a risk that the sector-specific capital the CFO has acquired during her or his career would be impaired. For such CFOs, deviation from the GAAP and legislation is therefore associated not only with the risk of not keeping their current position, but also with the threat of being unable to gain future jobs in the municipality sector which they have specialized in working in. These risks suggest that CFOs should be reluctant to engage in an opportunistic accounting choice unless they perceive strong political pressure to do so. This leads us to the following hypothesis:

H2b The probability of an opportunistic accounting choice decreases with prior working experience as a CFO in the municipal sector.

\subsubsection{CFO gender}

Another CFO characteristic that has been included in prior literature-and that is related to risk tolerance-is gender. Based on gender socialization theory, which assumes that an important and lasting socialization process occurs during childhood, males and females tend to have different attitudes, expectations and behaviours (Smith and Rogers 2000). In general, it has been suggested that female CFOs are more risk averse and ethical than male CFOs (e.g. Sun et al. 2019). However, occupational socialization theory suggests that the more important, lasting socialization takes place in adulthood (Smith and Rogers 2000), and that men and women within the same occupation will behave in a similar way (Betz et al. 1989).

The empirical results on the relationship between a CFO's gender and making an opportunistic accounting choice are not clear, as there are empirical results that support both theoretical suppositions. Empirical research in private sector settings have either found no gender difference or that female CFOs are associated with higher financial reporting quality (for a literature review, see Habib and Hossain 2013; Plöckinger et al. 2016). More specifically, a recent study on Italian municipalities found that female CFOs were less prone to engage in revenue misrepresentation than male CFOs (Anessi-Pessina and Sicilia 2019), which is in line with gender socialization theory. However, in line with occupational socialization theory, a recent study of listed corporations in Sweden - the same country setting as the present studyfound that CFO gender was not associated with financial reporting quality (Nasution and Jonnergård 2017). Considering the competing theoretical approaches and mixed empirical results, this hypothesis is stated in the null form: 
H3 The probability of opportunistic accounting choice is not associated with CFO gender.

\section{Method}

\subsection{Data selection}

The analysis presented in this paper is based on observations from 271 of Sweden's 290 municipalities. Gotland was excluded because it is a hybrid of a municipality and county council and is therefore not comparable with other Swedish municipalities. Another 18 municipalities were excluded due to a lack of complete data for all CFO variables.

Complete data for all non-CFO variables were, however, obtained from these 18 municipalities, which allowed us to control for differences between the municipalities included in the analysis $(n=271)$ and those that were excluded due to missing data $(n=18)$. A bivariate analysis showed significant differences for only four of the 32 variables included. Municipalities audited by EY were slightly overrepresented in the analysis, whereas municipalities in the regions of Stockholm and Gävleborg were slightly underrepresented. Furthermore, political competition was slightly higher in the municipalities included in the analysis. However, given that none of these control variables are important determinants of the measurement of accounting choice, the basic results are likely to be unaffected by this minor data loss.

CFO data were initially obtained from the 2017 CFO survey administered by Municipality Research in Western Sweden. The survey included information on gender, tenure and working experience for slightly more than $60 \%$ of the CFOs responsible for preparing the 2016 annual report. In order to minimize data loss, an effort was made to contact all non-responding CFOs. In the end, data were obtained from $93.7 \%$ of the CFOs. Except for the audit firm data, which was hand collected from audit reports or other municipal documents, all other variables are based on publicly available data from Statistics Sweden and the Swedish Association of Local Authorities and Regions.

\subsection{The dependent variable}

In the literature on financial reporting quality in public sector organizations, several different measurements are used. Studies addressing adjustments of reported financial performance typically use abnormalities in specific and/or total accruals to proxy for such adjustments (e.g. Ferreira et al. 2013; Arcas and Martí 2016; Greenwood et al. 2017; Beck 2018; Drew 2018). Studies focusing more specifically on compliance with regulations tend to use compliance indexes (e.g. Christiaens 1999; Carvalho et al. 2007; Christiaens and Van Peteghem 2007). Other studies focus on a specific accounting choice (e.g. Carpenter and Feroz 2001; Collin et al. 2009). In line with the latter, the opportunistic accounting choice analysed in this paper relates to a specific issue originating from a statement on revenue recognition of a 
government grant, issued by the standard-setting body within the Swedish municipal sector. The background to this grant relates to the rapid increase of asylum seekers in Sweden during the second half of 2015. In particular, numerous refugees from the Syrian war and Afghanistan arrived in Sweden. Sweden, which has 10 million inhabitants, received a total of 162,877 asylum seekers in 2015. This can be compared with the situation in 2005, when Sweden received about 20,000 asylum seekers (Swedish Migration Agency 2016). The increase in asylum seekers received a considerable amount of political and media attention. Important issues that were debated included how the distribution of refugees would be shared between different municipalities and how municipalities should be able to fund the additional costs of the increased refugee reception. While some municipalities received large numbers of refugees, other municipalities refused to accept any.

To address the issue of the allocation of refugees between different municipalities, a political settlement was made between the ruling parties of the central government and parts of the opposition. This settlement resulted in a law (no. 2016:38) stating that all municipalities are obliged to accept refugees for residency based on decisions from governmental agencies. To solve the municipalities' financial situation, the central government made an additional budgetary decision to allocate a total of 9.8 billion SEK to municipalities and county councils (Government bill no. 2015/16:47). The distribution of this grant between municipalities was based on how many refugees each municipality had accepted. The money was paid in December 2015 and, according to the letter of formal notice, was intended to cover costs for 2015 and 2016. This decision occurred near the closing date of the 2015 financial reports, as Swedish municipalities and county councils have a closing date of December 31. It immediately triggered an intensive debate about when this governmental grant should be reported as revenue.

The 9.8 billion SEK was paid out in December 2015 and was classified as a general grant. In the central government's financial reporting, the entire amount was accounted as an expense in 2015. According to accounting standard 18.1 issued by the SCMA, general grants should be recognized in the same period as the municipality receives the money, while targeted grants should be recognized as revenue when obligations and conditions are met. Thus, according to the standard, the revenue should have been recognized in 2015, when the central government accounted for the grant as an expense. However, according to the decision letter accompanying the grant, the grant was intended to cover costs for 2015 and 2016. The municipalities claimed that most of the costs were expected to occur during subsequent years. Reporting the entire amount as revenue in 2015-even though most costs would occur in 2016-would not be a major issue if it were not for the requirement of budget and reported surpluses every year.

Considering the intention of the grant, the timing of the grant announcement shortly before the closing date of the 2015 accounts (which meant that the municipalities were unable to consider this grant in their budgets) and the specific circumstances of the refugee situation, the SCMA proposed in a special statement that the grant could be accrued and recognized as revenue by 1/13 part in 2015 and 12/13 parts in 2016, and that a specific disclosure of the reporting procedure should be disclosed in the notes of the annual reports for 2015 and 2016. However, the entire 
grant was required to be recognized as revenue by the end of 2016 (SCMA 2015). Nevertheless, according to publicly available data from Statistics Sweden, approximately 1 billion SEK remained unrecognized as revenue by the end of 2016. We base our measurement of accounting choice on whether or not a municipality complied with the SCMA statement and recognized the grant before the end of 2016. Non-compliance is regarded as an opportunistic accounting choice. Hence, the dependent variable_-revenue recognition deviation — is a dummy variable for which municipalities that did not recognize the whole grant as revenue by the end of 2016 have a value of 1 , and other municipalities are assigned a value of 0 . This measure captures both a compliance issue and adjustments of reported financial performance, because non-compliance is a form of income-decreasing adjustment of reported financial performance.

\subsection{Independent variables}

CFO tenure is measured by the number of years in the current position. The number of years is also used to measure prior CFO experience in the municipal sector, other public sector and private sector. CFO gender is a dummy variable with a value of 1 for a female $\mathrm{CFO}$ and a value of 0 for a male $\mathrm{CFO}$.

\subsection{Control variables}

We control for several factors that, according to prior literature, may influence opportunistic accounting choice in public sector organizations. Considering that deviation from the SCMA statement had an income-decreasing effect on the reported financial performance during 2016, we also include variables that specifically control for incentives that are related to political and financial conditions.

\subsubsection{Financial position}

As previously described (Sect. 2), Swedish municipalities are required to report surpluses every year. If a deficit is reported, it should be recovered by an equivalent surplus within a 3-year period. However, the municipal council has the authority to decide not to restore the deficit if the municipality has a strong financial position. A weak financial position will thus reduce the leeway for political manoeuvres in relation to this restriction, and will therefore result in stronger incentives for governing parties in such municipalities to engage in an opportunistic accounting choice. On the other hand, financial distress attracts political attention and generates harsher scrutiny, making it necessary for an organization to signal accountability and responsibility (Ward et al. 1994). This suggests that the risk associated with deviating from the GAAP and legislation will be greater in municipalities with a weak financial position. Hence, there are arguments that support financial position as a factor affecting how the refugee grant was reported. Financial position is measured as equity, scaled by total assets. 


\subsubsection{Refugee grant}

As discussed above, there is always a political risk in deviating from the GAAP and legislation. Thus, if the deviation has only a marginal effect on the reported financial performance and position, politicians are probably less inclined to take the risk. On the other hand, municipalities that received large numbers of refugees probably had considerable costs related to the reception of the refugees, and thus actually used the money they received from the central government. The size of the refugee grant was therefore included as a control. This variable was measured as the total refugee grant the municipality received in December 2015, scaled by tax revenue and other governmental grants during that year.

\subsubsection{Surplus prior to recognition of the refugee grant}

The requirement of surpluses, which Swedish municipalities are obligated to comply with, is asymmetric in the sense that deficits are accumulated and are required to be restored within a 3-year period, whereas surplus is not accumulated over time (Sect. 2). This motivates politicians to use an opportunistic accounting choice to smooth the reported financial performance across the accounting periods (Stalebrink 2007; Donatella 2020b), in order to increase their political freedom of action in the future. Considering that deviation from the SCMA statement had an income-decreasing effect, the presence of a surplus prior to the recognition of the refugee grant is included as a dummy variable. Municipalities that would have reported a surplus even without recognizing the grant have a value of 1 , and other municipalities are assigned a value of 0 .

\subsubsection{Tax base}

From the perspective of economic theory, the activity of rational voters and their interest in municipal decisions can be explained by their level of economic input (Zimmerman 1977; Jensen and Payne 2005). However, a specific institutional feature in Sweden requires consideration. The central government considers the taxable capacity of municipalities when it allocates resources in the form of transfers and general grants to municipalities. The aim is to neutralize municipalities' income differences related to taxable capacity. Thus, municipalities with a taxable capacity (tax base/number of inhabitants) lower than the national average will receive a grant from the central government, while municipalities with a taxable capacity far above the national average will have to pay a fee to the central government. In this way, the variable of tax base captures both citizen attention and interest due to economic input, and the relative share of government grants a municipality has received. Consistent with prior literature (Rodríguez et al. 2013), we expect a negative association between tax base and opportunistic 
accounting choice. This variable was measured as the sum of all inhabitants' income and benefits in thousands of SEK, divided by the number of inhabitants.

\subsubsection{Size}

Several arguments have been made regarding control for size. In line with the assumptions in positive accounting theory, size may be used as a proxy for political attention (Watts and Zimmerman 1986). Furthermore, there are both coercive and normative arguments from an institutional perspective that indicate that compliance should increase with size (Falkman and Tagesson 2008). In line with previous studies in the Swedish setting, size is measured as the natural logarithm of residents in each municipality (e.g. Collin et al. 2017; Donatella et al. 2019).

\subsubsection{Political competition}

According to Zimmerman (1977), political environment is a factor that distinguishes the public sector from the private sector. Depending on the probability of a change in government, ruling parties who seek re-election (Zimmerman 1977; Copley et al. 1995) will have more or less strong incentives to signal accountability to the voters (Ward et al. 1994; Ferreira et al. 2013). Especially in the year before an election, which was the case for the annual report of 2017, a deficit can be used by the opposition as an argument against the ruling party. Municipalities that did not recognize the whole grant as revenue by the end of 2016, would thus have some flexibility in terms of artificially improving the reported financial performance during 2017. Considering this, we controlled for political competition, which is measured as the relative number of changes in government during the last five elections.

\subsubsection{Political affiliation mayor}

Swedish elections are essentially party elections (Hermansson 2016). Since the party organization controls the electorate processes, individual politicians have strong incentives to please the party in order to secure re-nomination in the next election. It is therefore logical that Swedish politicians generally tend to follow the party line to a greater extent than politicians in countries with a different election system (Karlsson 2013a). Moreover, senior politicians and members of the executive board show a particular tendency to follow the party line (Karlsson 2013b). Therefore, it can be expected that if the Swedish equivalent to the mayor (i.e. the chairman of the municipal board) is from the same political party as the ruling parties of the central government, the municipality will be more inclined to comply with the central government's intentions regarding the use of the grant. Municipalities in which the mayor has the same political affiliation as the prime minister and finance minister (i.e. Social Democrat) are assigned a value of 1 , and those of different political affiliation are assigned a value of 0 . 


\subsubsection{Audit firm}

Several audit firm characteristics may imply differences in audit quality between audit firms, which would influence their clients' likelihood of an opportunistic accounting choice (e.g. Francis 2011). This premise is supported by empirical research on Swedish municipalities, which has documented significant differences between the engaged audit firm and the financial reporting outcomes (e.g. Falkman and Tagesson 2008; Haraldsson and Tagesson 2014; Donatella et al. 2019; Donatella 2020b). In this study, the audit firms (Deloitte, EY, KPMG, and PwC) and municipalities' own audit offices were coded using five different dummy variables. The industry specialist $\mathrm{PwC}$ was used as a reference variable.

\subsubsection{Municipal networks}

Prior literature has observed that public sector organizations operating in close proximity to each other tend to resemble each other in terms of accounting choice and compliance (Carvalho et al. 2007; Donatella 2020a). As suggested by Donatella (2020a), in Sweden, this effect can be related to institutional pressure stemming from the professional environment municipalities operate in, because these organizations tend to co-operate with each other and meet peers from neighbouring municipalities. This view is consistent with the mimetic mechanism, which predicts that organizations operating within the same organizational fields will imitate each other in order to reduce uncertainty and ambiguity (e.g. DiMaggio and Powell 1983; Boxenbaum and Jonsson 2017). Membership within different professional and political networks may therefore play a major part in accounting choice (Carpenter and Feroz 2001).

As a proxy for a municipal network, we used the governmental administrative division of the country into regions. A dummy variable was used for each region, with the largest being used as the reference category. After the previously mentioned exclusion of Gotland, this left us with a total of 20 regions. These regions had an average of 14.5 municipalities each, varying from the largest region, Västra Götaland, with 49 municipalities, to the smallest region, Blekinge, with five municipalities.

\section{Results}

\subsection{Descriptive statistics}

As shown in Table 1, 22.5\% of the municipalities deviated from the statement issued by the SCMA and, consequently, adjusted their reported financial performance by making an accounting choice that decreased their income. Thus, by the end of 2016, 61 municipalities in the sample had still not recognized the whole grant as revenue. The CFO variables show variation in the sample, in terms of both tenure and prior CFO experience in different sectors. On average, CFO tenure was slightly more than 6 years, and prior $\mathrm{CFO}$ experience in the municipality sector, other public sector 
Table 1 Descriptive statistics

\begin{tabular}{|c|c|c|c|c|}
\hline Variable & Min & $\operatorname{Max}$ & Mean & SD \\
\hline Revenue recognition deviation & 0 (no) & 1 (yes) & 0.225 & 0.418 \\
\hline CFO tenure & 0.00 & 37.00 & 6.050 & 5.985 \\
\hline CFO experience-municipality sector & 0.00 & 23.00 & 2.490 & 4.540 \\
\hline CFO experience-other public sector & 0.00 & 22.00 & 0.450 & 2.090 \\
\hline CFO experience - private sector & 0.00 & 30.00 & 1.18 & 3.647 \\
\hline CFO gender & 0 (male) & 1 (female) & 0.446 & 0.498 \\
\hline Financial position & -0.56 & 0.70 & 0.141 & 0.200 \\
\hline Refugee grant & 0.00 & 0.14 & 0.025 & 0.022 \\
\hline Surplus & 0 (no) & 1 (yes) & 0.720 & 0.450 \\
\hline Tax base & 142.37 & 294.94 & 180.519 & 20.618 \\
\hline Size & 7.81 & 13.75 & 9.847 & 0.970 \\
\hline Political competition & 0.00 & 1.00 & 0.349 & 0.257 \\
\hline Social Democrat mayor & 0 (no) & 1 (yes) & 0.642 & 0.480 \\
\hline \multicolumn{5}{|l|}{ Audit firm } \\
\hline Deloitte & 0 (no) & 1 (yes) & 0.059 & 0.236 \\
\hline EY & 0 (no) & 1 (yes) & 0.155 & 0.363 \\
\hline KPMG & 0 (no) & 1 (yes) & 0.262 & 0.441 \\
\hline Own office & 0 (no) & 1 (yes) & 0.048 & 0.214 \\
\hline PwC & 0 (no) & 1 (yes) & 0.476 & 0.500 \\
\hline \multicolumn{5}{|l|}{ Municipal networks } \\
\hline Blekinge & 0 (no) & 1 (yes) & 0.018 & 0.135 \\
\hline Dalarna & 0 (no) & 1 (yes) & 0.048 & 0.214 \\
\hline Gävleborg & 0 (no) & 1 (yes) & 0.030 & 0.170 \\
\hline Halland & 0 (no) & 1 (yes) & 0.022 & 0.147 \\
\hline Jämtland & 0 (no) & 1 (yes) & 0.030 & 0.170 \\
\hline Jönköping & 0 (no) & 1 (yes) & 0.044 & 0.206 \\
\hline Kalmar & 0 (no) & 1 (yes) & 0.041 & 0.198 \\
\hline Kronoberg & 0 (no) & 1 (yes) & 0.030 & 0.170 \\
\hline Norrbotten & 0 (no) & 1 (yes) & 0.044 & 0.206 \\
\hline Stockholm & 0 (no) & 1 (yes) & 0.081 & 0.274 \\
\hline Skåne & 0 (no) & 1 (yes) & 0.118 & 0.323 \\
\hline Södermaland & 0 (no) & 1 (yes) & 0.033 & 0.180 \\
\hline Värmland & 0 (no) & 1 (yes) & 0.055 & 0.229 \\
\hline Västerbotten & 0 (no) & 1 (yes) & 0.055 & 0.229 \\
\hline Västernorrland & 0 (no) & 1 (yes) & 0.026 & 0.159 \\
\hline Västmaland & 0 (no) & 1 (yes) & 0.037 & 0.189 \\
\hline Västra Götaland & 0 (no) & 1 (yes) & 0.173 & 0.379 \\
\hline Uppland & 0 (no) & 1 (yes) & 0.026 & 0.159 \\
\hline Örebro & 0 (no) & 1 (yes) & 0.044 & 0.206 \\
\hline Östergötland & 0 (no) & 1 (yes) & 0.044 & 0.206 \\
\hline
\end{tabular}

Descriptive statistics for all variables included in the regression analysis $(n=271)$ 
settings and the private sector was around 2.5 years, 0.5 year, and 1.2 years, respectively. Almost $45 \%$ of the CFOs were females.

The variation in financial position is large among the municipalities. However, two-thirds of the municipalities would have shown a surplus for 2016, even without receiving the refugee grant. On average, the refugee grant was $2.5 \%$ of the tax revenues and other government grants, and the tax base was 180519 SEK. Political competition indicates that there was a change in government every third election, on average. The position of mayor is dominated by representatives of the Social Democrat Party, with just over two-thirds of the municipalities having a Social Democrat mayor. $\mathrm{PwC}$ is the dominant player among the audit firms, with almost $50 \%$ of the audit assignments.

\subsection{Analysis}

The first step of the analysis involves examining bivariate correlations to assess the presence of multicollinearity across the independent variables in the model. The most common indicator of multicollinearity is the correlation coefficient. If this coefficient exceeds 0.8 , it signals a problem, since the standard error is likely to be affected (Djurfeldt et al. 2007). As can be seen in the correlation matrix in Table 2, none of the pair-wise correlations exceeds 0.8 , and the highest correlations are 0.608 (size and tax base). An additional collinearity test confirmed the absence of collinearity problems, as all the VIF values for the variables were below the critical threshold of 2.5 (e.g. Djurfeldt et al. 2007).

Table 2 indicates a significant correlation between the dependent variable revenue recognition deviation and three of the independent variables. Whereas $C F O$ tenure and $C F O$ experience-municipality are significantly negatively associated with the dependent variable, $C F O$ experience-private sector is significantly positively associated. However, neither the variable $C F O$ gender nor the variable $C F O$ experience-other public sector is significantly correlated with the dependent variable.

Table 3 presents three regression models. Model 1 includes only the control variables derived from economic and institutional theories. The variables financial position, surplus, tax base, and Social Democrat mayor are all significant. The dummy variables representing municipal networks show that there are differences among the networks. The negative significant relationship between the dependent variable and the variable financial position indicates that municipalities with a weak financial position are more inclined to engage in income smoothing. This indication is strengthened by the fact that there is a positive and significant relationship between the dependent variable and the variable surplus. As expected, there is a significant negative relationship between the dependent variable and tax base. Furthermore, the political variable Social Democrat mayor is significant and has the expected sign. Three of the 19 regions included in the model that was used to proxy municipal networks differ significantly from the reference variable. These regions are Jönköping, Kalmar and Skåne, which include 13, 12 and 33 municipalities, respectively. These regions differ in size and are not in geographical proximity to each other. This model is significant, and correctly classifies $82.7 \%$ of the cases. Compared with the naïve 


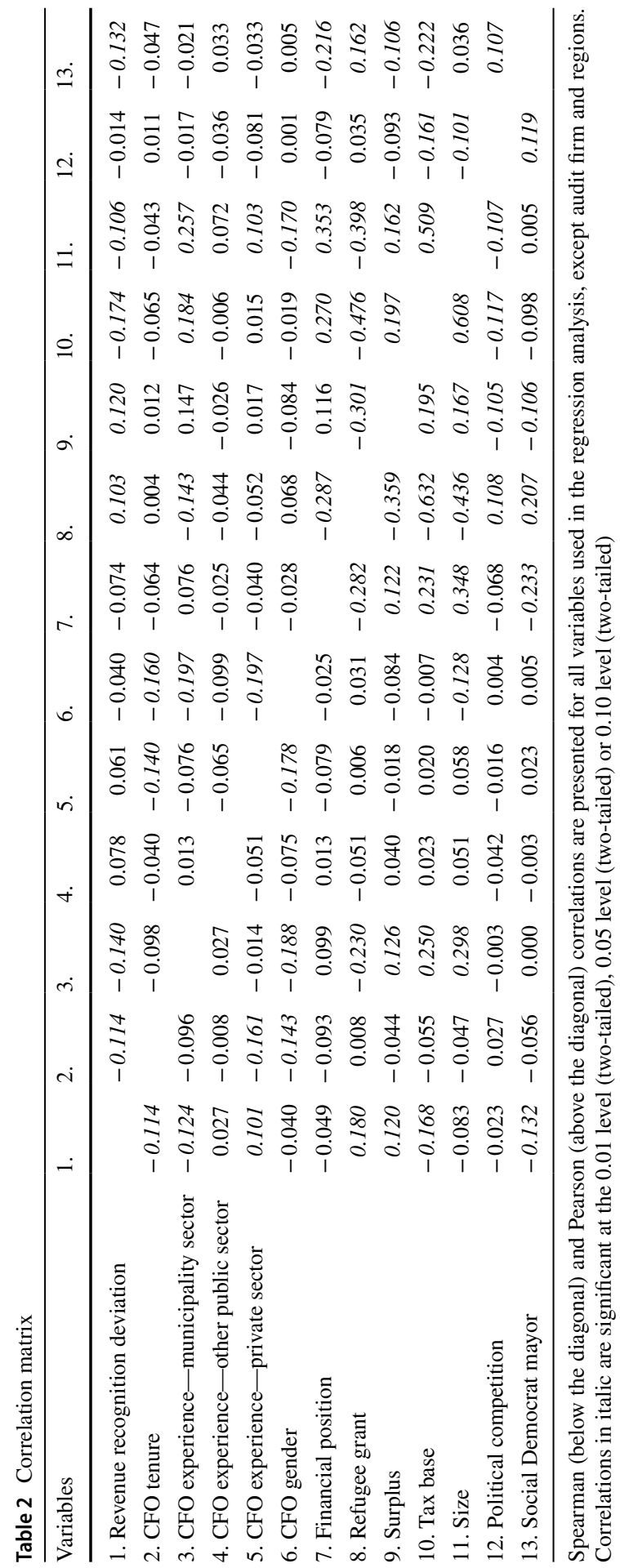




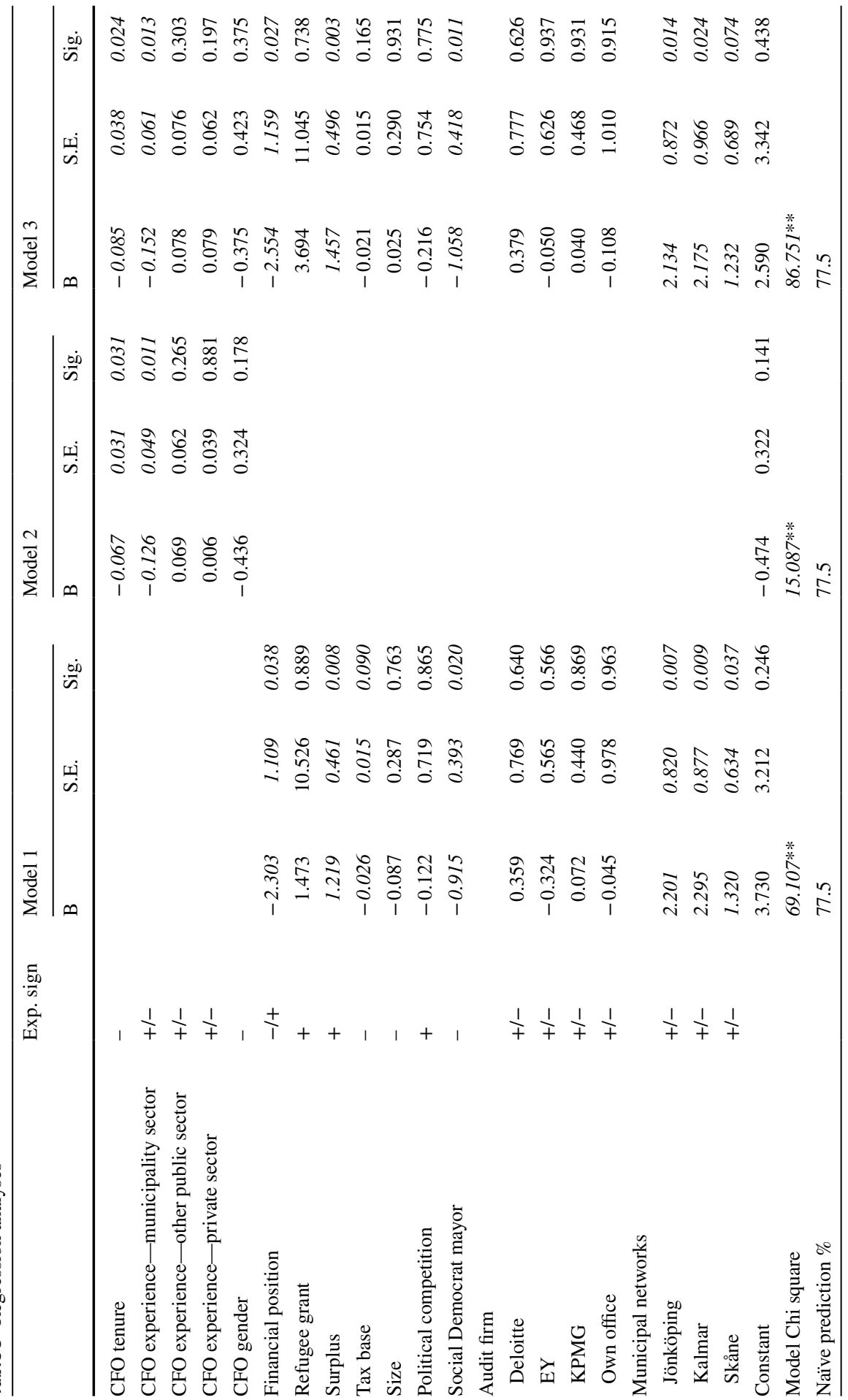




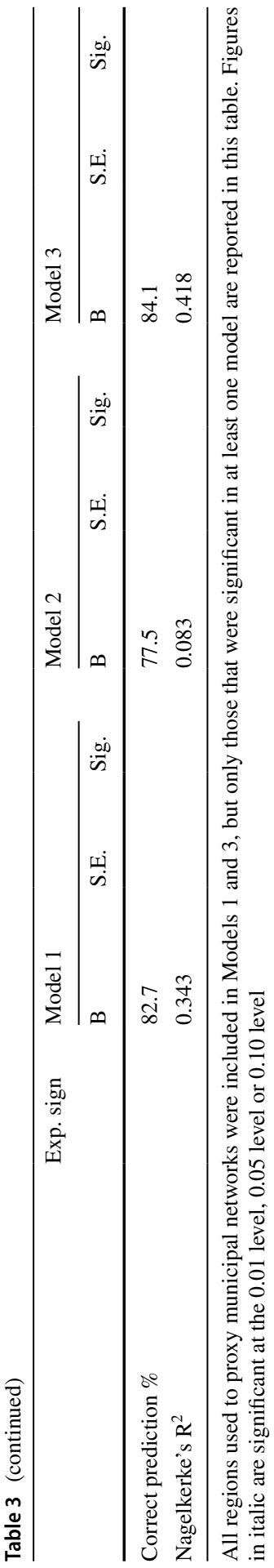


model, this is an improvement of $5.2 \%$. The explanatory power, measured as the Nagelkerke's $\mathrm{R}^{2}$, is $34.3 \%$.

Model 2 includes the $\mathrm{CFO}$ variables derived from upper echelons theory. As expected, the variable $C F O$ tenure is significantly negatively correlated with the dependent variable. Hence, the results align with $\mathrm{H} 1$, which predicts that the probability of revenue recognition deviation decreases with $\mathrm{CFO}$ tenure. Of the variables measuring prior $\mathrm{CFO}$ experience from different sectors, only the variable $\mathrm{CFO}$ experience-municipality is significant and negative. Overall, these results align with $\mathrm{H} 2 \mathrm{~b}$, but not with $\mathrm{H} 2 \mathrm{a}$. More specifically, our result suggests that prior CFO experience in the municipal sector decreases the probability of deviation, while prior CFO experience in other sectors does not significantly affect the probability of deviation. The variable $C F O$ gender is not significant, and the null hypothesis (H3), which states that the probability of an opportunistic accounting choice is not associated with CFO gender, cannot be rejected. This model is significant, with an explanatory power, measured as a Nagelkerke's $\mathrm{R}^{2}$ of $8.3 \%$. However, the percentage that is correctly classified is the same as that in the naive model.

Model 3 includes all variables. With one exception, all the variables that were significant in Models 1 and 2 are also significant in the full model. The exception is the variable tax base, which was moderately significant in Model 1 but is insignificant in Model 3. Even when we control for factors derived from economic and institutional theories, the basic results regarding the hypotheses hold the same basic relationship. Hence, $\mathrm{H} 1$ and $\mathrm{H} 2 \mathrm{~b}$ are consistently supported by our analysis. In contrast, $\mathrm{H} 2 \mathrm{a}$ is not supported, while $\mathrm{H} 3$ (which is stated in null form) cannot be rejected.

The full model is significant, and correctly classifies $84.1 \%$ of the cases. Compared with the naïve model, this is an improvement of $6.6 \%$. The explanatory power, measured as Nagelkerke's $\mathrm{R}^{2}$, is $41.8 \%$. Hence, the full model, which includes all variables derived from economic theory, institutional theory and upper echelon theory, has the strongest explanatory power and the ability to correctly classify revenue recognition deviation. Compared with Model 1, Model 3 improves the explanatory power by $7.5 \%$. In terms of correct classification, the improvement from Model 1 to Model 3 is $1.4 \%$.

Additional non-tabulated results support the presented analysis. We examined the interactions of the prior experience variables with each other and found no significant interaction effects. Including these interaction variables in the model does not change the basic results reported in Models 1, 2 and 3. We also examined the interactions of $\mathrm{CFO}$ tenure with the prior experience variables. Adding these variables to the model produces no significant interaction effects. However, this lack of interaction effects is due to problems with multicollinearity, as indicated by the VIF values for the interaction variables and the experience variables, which range from 5.4 to 8.4. If the variables capturing prior CFO experience are excluded from the model, and the variables in which $C F O$ tenure interacts with prior $C F O$ experience are included, then the variable $C F O$ tenure $\times C F O$ experience-municipality is significant and is negatively correlated with the dependent variable. $C F O$ tenure $\times C F O$ experience-other public sector and $\mathrm{CFO}$ tenure $\times C F O$ experience-private sector are positively correlated with the dependent variable, but are not significant. 


\section{Conclusions}

In this study, we have tested a model of opportunistic accounting choice on a sample of Swedish municipalities. More specifically, we used a direct measure that captures revenue recognition of a governmental grant in order to analyse and explain opportunistic accounting choice. In this final section, we discuss the results and our hypotheses in light of the empirical testing, and draw conclusions from the discussion. Accordingly, we now turn to a discussion of the predictions and outcomes of the test, in order to reach our main theoretical conclusion: that a concurrence between different theories can contribute to improving the explanation of opportunistic accounting choice.

In line with previous research, our study shows that both economic and institutional-related arguments have explanatory power that can help to predict and explain financial reporting quality in public sector organizations. However, in addition to the traditional premises of economic and institutional theory, we have added a third premise based on individual characteristics (i.e. upper echelons theory) in order to explain decision-making in relation to opportunistic accounting choice. In line with the suggestion of Hambrick and Mason (1984) and the method used in many studies addressing financial reporting outcomes in the private sector (Plöckinger et al. 2016), we have relied on observable managerial characteristics. Considering the empirical phenomenon of our study, in which we analyse revenue recognition of a governmental grant, it was justified to focus on the CFO's characteristics because CFOs are more likely than other senior officials to affect accruals through accounting decisions (Dejong and Ling 2013).

Finally, regarding our hypotheses of $\mathrm{CFO}$ characteristics, CFO tenure and prior $\mathrm{CFO}$ experience do indeed add explanatory power to our analysis of opportunistic accounting choice. More precisely, the probability of revenue recognition deviation-and thus of income-decreasing adjustments of reported financial performance-is negatively associated with $C F O$ tenure. Our interpretation of this finding is that the organizational-specific human capital that comes with tenure brings ability and credibility that allow the CFO to have influence over the political process, meaning that the $\mathrm{CFO}$ gains greater room for manoeuvring and decision-making based on professional norms. Prior $\mathrm{CFO}$ experience did influence the probability of opportunistic accounting choice; CFOs with prior $\mathrm{CFO}$ experience in the municipal sector were less inclined to deviate. This finding indicates that sector-specific human capital is of greater importance in gaining influence over the political process than more general occupation capital. However, in contrast to the findings of Anessi-Pessina and Sicilia (2019), gender was not an important determinant of opportunistic accounting choice in our study. This finding may be due to the Swedish context, and may not necessarily be generalizable to the conditions prevailing in other countries. Different countries can be assumed to have different social values (Hofstede 1983), something that also is likely to be reflected in financial reporting practice (e.g. Gray 1988; Braun and Rodriguez 2008; Tagesson et al. 2012). In their study on gender and financial reporting quality in Swedish listed corporations, Nasution and Jonnergård (2017) 
noted that Sweden is ranked as a gender-equal country and, based on Hofstede's cultural dimension, is classified as a feminine society. They also noticed that studies that found an association between gender and financial reporting quality were conducted in more masculine societies. Whether such differences apply to public sector financial reporting is a matter for future research.

Our main conclusion is that the explanatory power of opportunistic accounting choice increases with the use of an eclectic approach with theoretical concurrence that includes economic conditions, agency, institutional forces and conditions, and behavioural factors that reflect the characteristics and idiosyncrasies of individuals.

Acknowledgements Open access funding provided by Linköping University.

Open Access This article is licensed under a Creative Commons Attribution 4.0 International License, which permits use, sharing, adaptation, distribution and reproduction in any medium or format, as long as you give appropriate credit to the original author(s) and the source, provide a link to the Creative Commons licence, and indicate if changes were made. The images or other third party material in this article are included in the article's Creative Commons licence, unless indicated otherwise in a credit line to the material. If material is not included in the article's Creative Commons licence and your intended use is not permitted by statutory regulation or exceeds the permitted use, you will need to obtain permission directly from the copyright holder. To view a copy of this licence, visit http://creativecommons.org/licen ses/by/4.0/.

\section{References}

Ada, S. S., \& Christiaens, J. (2017). Why do some municipalities apply accrual-based rules more than others? Evidence from Turkey. Economics and Management, 20(3), 189-206. https://doi. org/10.15240/tul/001/2017-3-013.

Aier, J. K., Comprix, J., Gunlock, M. T., \& Lee, D. (2005). The financial expertise of CFOs and accounting restatements. Accounting Horizons, 19(3), 123-135. https://doi.org/10.2308/acch.2005.19.3.123.

Ali, A., \& Zhang, W. (2015). CEO tenure and earnings management. Journal of Accounting and Economics, 59(1), 60-79. https://doi.org/10.1016/j.jacceco.2014.11.004.

Anderson, R., Maks, H., \& Klaassen, H. (2019). An exploratory study assessing compliance among municipal controllers and the possible explanations for their degree of compliance. Journal of Public Affairs. https://doi.org/10.1002/pa.2068.

Anessi-Pessina, E., \& Sicilia, M. (2019). Do top managers' individual characteristics affect accounting manipulation in the public sector? Journal of Public Administration Research and Theory, 30, 465484. https://doi.org/10.1093/jopart/muz038.

Arcas, M. J., \& Martí, C. (2016). Financial performance adjustments in English local governments. Australian Accounting Review, 77(26), 141-152. https://doi.org/10.1111/auar.12094.

Ballantine, J., Forker, J., \& Greenwood, M. (2007). Earnings management in English NHS hospital trusts. Financial Accountability \& Management, 23(4), 421-440. https://doi.org/10.111 1/j.1468-0408.2007.00436.x.

Beck, A. W. (2018). Opportunistic financial reporting around municipal bond issues. Review of Accounting Studies, 23(3), 785-826. https://doi.org/10.1007/s11142-018-9454-2.

Betz, M., O'Connell, L., \& Shepard, J. M. (1989). Gender differences in proclivity for unethical behavior. Journal of Business Ethics, 8(5), 321-324.

Boxenbaum, E., \& Jonsson, S. (2017). Isomorphism, diffusion and decoupling: Concept evolution and theoretical challenges. In R. Greenwood, C. Oliver, T. B. Lawrence, \& R. E. Meyer (Eds.), The SAGE handbook of organizational institutionalism (pp. 79-104). Thousand Oaks: Sage.

Braun, G. P., \& Rodriguez, R. P., Jr. (2008). Earnings management and accounting values: A test of gray (1988). Journal of International Accounting Research, 7(2), 1-23. https://doi.org/10.2308/ jiar.2008.7.2.1. 
Brorström, B. (1997). För den goda redovisningsseden [Towards good accounting practice]. Lund: Studentlitteratur.

Carpenter, V. L., \& Feroz, E. H. (2001). Institutional theory and accounting rule choice: An analysis of four US state governments' decisions to adopt generally accepted accounting principles. Accounting, Organizations and Society, 26(7-8), 565-596. https://doi.org/10.1016/S0361-3682(00)00038-6.

Carvalho, J. B., Camões, P. J., Jorge, S. M., \& Fernandes, M. J. (2007). Conformity and diversity of accounting and financial reporting practices in Portuguese local government. Canadian Journal of Administrative Science, 24(1), 2-14. https://doi.org/10.1002/cjas.1.

Castanias, R. P., \& Helfat, C. E. (1991). Managerial resources and rents. Journal of Management, 17(1), 155-171. https://doi.org/10.1177/014920639101700110.

Castanias, R. P., \& Helfat, C. E. (2001). The managerial rents model: Theory and empirical analysis. Journal of Management, 27(6), 661-678. https://doi.org/10.1177/014920630102700604.

Christiaens, J. (1999). Financial accounting reform in Flemish municipalities: An empirical investigation. Financial Accountability \& Management, 15(1), 21-40. https://doi.org/10.1111/14680408.00072 .

Christiaens, J., \& Van Peteghem, V. (2007). Governmental accounting reform: Evolution of the implementation in Flemish municipalities. Financial Accountability \& Management, 23(4), 375-399. https://doi.org/10.1111/j.1468-0408.2007.00434.x.

Cohen, S., Bisogno, M., \& Malkogianni, I. (2019). Earnings management in local governments: The role of political factors. Journal of Applied Accounting Research, 20(3), 331-348. https://doi. org/10.1108/JAAR-10-2018-0162.

Collin, S.-O., Haraldsson, M., Tagesson, T., \& Blank, V. (2017). Explaining municipal audit cost in Sweden: Reconsidering the political environment, the municipal organization and the audit market. Financial Accountability \& Management, 33(4), 391-405. https://doi.org/10.1111/ faam. 12130 .

Collin, S. O. Y., Tagesson, T., Andersson, A., Cato, J., \& Hansson, K. (2009). Explaining the choice of accounting standards in municipal corporations: Positive accounting theory and institutional theory as competitive or concurrent theories. Critical Perspectives on Accounting, 20(2), 141-174. https:// doi.org/10.1016/j.cpa.2008.09.003.

Copley, P. A., Gaver, J. J., \& Gaver, K. M. (1995). Simultaneous estimation of the supply and demand of differentiated audits: Evidence from the municipal audit market. Journal of Accounting Research, 33(1), 137-155. https://doi.org/10.2307/2491296.

Cyert, R. M., \& March, J. G. (1963). A behavioral theory of the firm. Englewood Cliffs: Prentice-Hall.

Dejong, D., \& Ling, Z. (2013). Managers: Their effects on accruals and firm policies. Journal of Business Finance \& Accounting, 40(1-2), 82-114. https://doi.org/10.1111/jbfa.12012.

DiMaggio, P., \& Powell, W. W. (1983). The iron cage revisited: Collective rationality and institutional isomorphism in organizational fields. American Sociological Review, 48(2), 147-160.

Djurfeldt, G., Larsson, R., \& Stjärnhagen, O. (2007). Statistisk verktygslåda [Statistical toolbox]. Lund: Studentlitteratur.

Donatella, P. (2020a). Determinants of mandatory disclosure compliance in Swedish municipalities. Journal of Public Budgeting, Accounting \& Financial Management. https://doi.org/10.1108/JPBAF M-03-2019-0048.

Donatella, P. (2020b). Is political competition a driver of financial performance adjustments? An examination of Swedish municipalities. Public Money \& Management, 40(2), 122-130. https://doi. org/10.1080/09540962.2019.1667684.

Donatella, P., Haraldsson, M., \& Tagesson, T. (2019). Do audit firm and audit costs/fees influence earnings management in Swedish municipalities? International Review of Administrative Sciences, 85(4), 673-691. https://doi.org/10.1177/0020852317748730.

Downs, A. (1957). An economic theory of democracy. New York: Harper \& Row.

Drew, J. (2018). Playing for keeps: Local government distortion of depreciation accruals in response to high-stakes public policy-making. Public Money \& Management, 38(1), 57-64. https://doi. org/10.1080/09540962.2017.1389542.

Esteve, M., Boyne, G., Sierra, V., \& Ysa, T. (2013). Organizational collaboration in the public sector: Do chief executives make a difference? Journal of Public Administration Research and Theory, 23(4), 927-952. https://doi.org/10.1093/jopart/mus035.

Falkman, P., \& Tagesson, T. (2008). Accrual accounting does not necessarily mean accrual accounting: Factors that counteract compliance with accounting standards in Swedish municipal 
accounting. Scandinavian Journal of Management, 24(3), 271-283. https://doi.org/10.1016/j.scama n.2008.02.004.

Feng, M., Ge, W., Luo, S., \& Shevlin, T. (2011). Why do CFOs become involved in material accounting manipulations? Journal of Accounting and Economics, 51(1-2), 21-36. https://doi.org/10.1016/j. jacceco.2010.09.005.

Ferreira, A., Carvalho, J., \& Pinho, F. (2013). Earnings management around zero: A motivation to local politician signalling competence. Public Management Review, 15(5), 657-686. https://doi. org/10.1080/14719037.2012.707679.

Finkelstein, S., \& Hambrick, D. (1990). Top-management-team tenure and organizational outcomes: The moderating role of managerial discretion. Administrative Science Quarterly, 35(3), 484-503. https:// doi.org/10.2307/2393314.

Francis, J. R. (2011). A framework for understanding and researching audit quality. Auditing: A Journal of Practice \& Theory, 30(2), 125-152. https://doi.org/10.2308/ajpt-50006.

Ge, W., Matsumoto, D., \& Zhang, J. L. (2011). Do CFOs have style? An empirical investigation of the effect of individual CFOs on accounting practices. Contemporary Accounting Research, 28(4), 1141-1179. https://doi.org/10.1111/j.1911-3846.2011.01097.x.

Giroux, G., \& Deis, D. (1993). Investor interests and government accounting disclosure. Accounting, Auditing \& Accountability Journal, 6(1), 63-78. https://doi.org/10.1108/09513579310027530.

Government bill no. 2015/16:47. Extra additional budget for 2015.

Gray, S. J. (1988). Towards a theory of cultural influence on the development of accounting systems internationally. ABACUS, 24(1), 1-15. https://doi.org/10.1111/j.1467-6281.1988.tb00200.x.

Greenwood, M. J., Baylis, R. M., \& Tao, L. (2017). Regulatory incentives and financial reporting quality in public healthcare organisations. Accounting and Business Research, 47(7), 831-855. https://doi. org/10.1080/00014788.2017.1343116.

Habib, A., \& Hossain, M. (2013). CEO/CFO characteristics and financial reporting quality: A review. Research in Accounting Regulation, 25(1), 88-100. https://doi.org/10.1016/j.racreg.2012.11.002.

Hambrick, D. (2007). Upper echelons theory: An update. Academy of Management Review, 32(2), 334343. https://doi.org/10.5465/amr.2007.24345254.

Hambrick, D. C., \& Finkelstein, S. (1987). Managerial discretion: A bridge between polar views of organizational outcomes. Research in Organizational Behavior, 9, 369-406.

Hambrick, D. C., \& Mason, P. A. (1984). Upper echelons: The organization as a reflection of its top managers. Academy of Management Review, 9(2), 193-206. https://doi.org/10.5465/amr.1984.4277628.

Haraldsson, M., \& Tagesson, T. (2014). Compromise and avoidance: The response to new legislation. Journal of Accounting \& Organizational Change, 10(3), 288-313. https://doi.org/10.1108/ JAOC-10-2012-0096.

Hazarika, S., Karpoff, J. M., \& Nahata, R. (2012). Internal corporate governance, CEO turnover, and earnings management. Journal of Financial Economics, 104(1), 44-69. https://doi.org/10.1016/j. jfineco.2011.10.011.

Hermansson, J. (2016). The election system. In J. Pierre (Ed.), The Oxford handbook of Swedish politics (pp. 103-114). Oxford: Oxford University Press.

Hiebl, M. R. (2014). Upper echelons theory in management accounting and control research. Journal of Management Control, 24(3), 223-240. https://doi.org/10.1007/s00187-013-0183-1.

Hofstede, G. (1983). The cultural relativity of organizational practices and theories. Journal of International Business Studies, 14(2), 75-89. https://doi.org/10.1057/palgrave.jibs.8490867.

Ibrahim, S., Noikokyris, E., Fabiano, G., \& Favato, G. (2019). Manipulation of profits in Italian publicly-funded healthcare trusts. Public Money \& Management, 39(6), 428-435. https://doi. org/10.1080/09540962.2019.1578539.

Ingram, R. W. (1984). Economic incentives and the choice of state government accounting practices. Journal of Accounting Research, 22(1), 126-144. https://doi.org/10.2307/2490704.

Jensen, K. L., \& Payne, J. L. (2005). Audit procurement: Managing audit quality and audit fees in response to agency costs. Auditing: A Journal of Practice \& Theory, 24(2), 27-48. https://doi. org/10.2308/aud.2005.24.2.27.

Jones, R., \& Pendlebury, M. (1982). Uniformity v. flexibility in the published accounts of local authorities: The UK problem and some European solutions. Accounting and Business Research, 12(46), 129-135. https://doi.org/10.1080/00014788.1982.9728799.

Jones, R., \& Pendlebury, M. (1991). The published accounts of local authorities, revisited. Financial Accountability \& Management, 7(1), 15-33. https://doi.org/10.1111/j.1468-0408.1991.tb00337.x. 
Jones, R., \& Pendlebury, M. (2004). A theory of the published accounts of local authorities. Financial Accountability \& Management, 20(3), 305-325. https://doi.org/10.1111/j.0267-4424.2004.00386.x.

Karlsson, D. (2013a). The hidden constitutions: How informal political institutions affect the representation style of local councils. Local Government Studies, 39(5), 681-702. https://doi. org/10.1080/03003930.2012.670748.

Karlsson, D. (2013b). Who do the local councillors of Europe represent? In B. Egner, D. Sweeting, \& P. J. Klok (Eds.), Local councillors in Europe (pp. 97-119). Wiesbaden: Springer.

Law (no. 2016:38) On receipt of certain newly arrived immigrants for residence [Lag om mottagande av vissa nyanlända invandrare för bosättning].

Leone, A. J., \& Liu, M. (2010). Accounting irregularities and executive turnover in founder-managed firms. The Accounting Review, 85(1), 287-314. https://doi.org/10.2308/accr.2010.85.1.287.

Lin, Z. J., Baxter, G. C., \& Murphy, G. J. (1993). Improving government financial reporting in Canada: An evaluation of compliance with the PSAAC's accounting and reporting standards for governments. Financial Accountability \& Management, 9(4), 235-254. https://doi.org/10.1111/j.1468-0408.1993. tb00376.x.

Meyer, J. W., \& Rowan, B. (1977). Institutionalized organizations: Formal structure as myth and ceremony. American Journal of Sociology, 83(2), 340-363. https://doi.org/10.1086/226550.

Montin, S. (2015). Municipalities, regions, and county councils. In J. Pierre (Ed.), The Oxford handbook of Swedish politics (pp. 367-382). Oxford: Oxford University Press. https://doi.org/10.1093/oxfor dhb/9780199665679.013.22.

Nasution, D., \& Jonnergård, K. (2017). Do auditor and CFO gender matter to earnings quality? Evidence from Sweden. Gender in Management: An International Journal, 32(6), 330-351. https://doi. org/10.1108/GM-06-2016-0125.

Nielsen, S. (2010). Top management team diversity: A review of theories and methodologies. International Journal of Management Reviews, 12(3), 301-316. https://doi.org/10.111 1/j.1468-2370.2009.00263.x.

Pilcher, R., \& Van der Zhan, M. (2010). Local governments, unexpected depreciation and financial performance adjustment. Financial Accountability \& Management, 26(3), 299-324. https://doi.org/10.1 111/j.1468-0408.2010.00503.x.

Pina, V., Arcas, M. J., \& Marti, C. (2012). Accruals and 'accounting numbers management' in UK executive agencies. Public Money \& Management, 32(4), 273-280. https://doi.org/10.1080/09540 962.2012.691306.

Plöckinger, M., Aschaue, E., Hiebl, M. R. W., \& Rohatsche, R. (2016). The influence of individual executives on corporate financial reporting: A review and outlook from the perspective of upper echelons theory. Journal of Accounting Literature, 37, 55-75. https://doi.org/10.1016/j.acclit.2016.09.002.

PwC. (2014). Collection of information related to the potential impact, including costs, of implementing accrual accounting in the public sector and technical analysis of the suitability of individual IPSAS standards 2013/S 107-182395. Eurostat. https://ec.europa.eu/eurostat. Accessed 12 Sept 2016.

Rodríguez, M. P., Alcaide, L., \& López, A. M. (2013). Determinants of financial transparency in government. International Public Management Journal, 16(4), 557-602. https://doi.org/10.1080/10967 494.2013.849169.

Schrand, C. M., \& Zechman, S. L. (2012). Executive overconfidence and the slippery slope to financial misreporting. Journal of Accounting and Economics, 53(1-2), 311-329. https://doi.org/10.1016/j. jacceco.2011.09.001.

SCMA. (2015). Statement on accounting and accrual of government grants provided to temporary support municipalities and county councils in the current refugee situation [Yttrande om redovisning och periodisering av statsbidrag som ges som tillfälligt stöd till kommuner och landsting för att hantera den rådande flyktingsituationen]. SCMA special statement.

Smith, A., \& Rogers, V. (2000). Ethics-related responses to specific situation vignettes: Evidence of gender-based differences and occupational socialization. Journal of Business Ethics, 28(1), 73-85. https ://doi.org/10.1023/A:1006388923834.

Stalebrink, O. J. (2007). An investigation of discretionary accruals and surplus-deficit management: Evidence from Swedish municipalities. Financial Accountability \& Management, 23(4), 441-457. https ://doi.org/10.1111/j.1468-0408.2007.00437.x.

Sun, J., Kent, P., Qi, B., \& Wang, J. (2019). Chief financial officer demographic characteristics and fraudulent financial reporting in China. Accounting \& Finance, 59(4), 2705-2734. https://doi. org/10.1111/acfi.12286.

Swedish Migration Agency. (2016). Annual report 2015 [Årsredovisning 2015, Migrationsverket]. 
Tagesson, T., Glinatsi, N. A., \& Prahl, M. (2015). Procurement of audit services in the municipal sector: The impact of competition. Public Money \& Management, 35(4), 273-280. https://doi. org/10.1080/09540962.2015.1047270.

Tagesson, T., \& Grossi, G. (2015). Chapter 13: Public sector accounting and auditing in Sweden. In I. Brusca, E. Caperchione, S. Cohen, \& F. M. Rossi (Eds.), Public sector accounting and auditing in Europe - the challenge of harmonization (pp. 189-203). London: Palgrave Macmillan.

Tagesson, T., Gujic, B., \& Petrovic, K. (2012). Secrecy versus transparency-A comparative study of social and environmental disclosure practice in Croatian and Swedish corporations. Journal of EastWest Business, 18(4), 321-336. https://doi.org/10.1080/10669868.2012.747119.

Ward, D. D., Elder, R. J., \& Kattelus, S. C. (1994). Further evidence on the determinants of municipal audit fees. Accounting Review, 69(2), 399-411.

Watts, R. L., \& Zimmerman, J. L. (1986). Positive accounting theory. New Jersey: Prentice-Hall.

Yamak, S., Nielsen, S., \& Escribá-Esteve, A. (2014). The role of external environment in upper echelons theory: A review of existing literature and future research directions. Group \& Organization Management, 39(1), 69-109. https://doi.org/10.1177/1059601113511663.

Zimmerman, J. (1977). The municipal accounting maze: An analysis of political incentive. Journal of Accounting Research, 15, 107-144. https://doi.org/10.2307/2490636.

Publisher's Note Springer Nature remains neutral with regard to jurisdictional claims in published maps and institutional affiliations.

Pierre Donatella is senior lecturer of public administration at the School of Public Administration, University of Gothenburg (Sweden). He received his Ph.D. in Business administration from the School of Business, Economics and Law, University of Gothenburg, in 2016. He is the author of several articles on public sector accounting and auditing.

Torbjörn Tagesson is Professor of Accounting at Linköping University (Sweden) and the Executive Director of the Swedish Council for Municipal Accounting. He received his Ph.D. in Business Administration from Lund University (Sweden) in 2002 and is the author of several books and articles on accounting, auditing, and public administration. 